\title{
REVIEW
}

\section{Air pollution affects food security in China: taking ozone as an example}

\author{
Zhaozhong FENG ${ }^{1}$, Xuejun LIU (凶) ${ }^{2}$, Fusuo ZHANG ${ }^{2}$ \\ 1 State Key Laboratory of Urban and Regional Ecology, Research Center for Eco-Environmental Sciences, Chinese Academy of Sciences, \\ Beijing 100085, China \\ 2 College of Resources and Environmental Sciences, China Agricultural University, Beijing 100193, China
}

\begin{abstract}
Air pollution is becoming an increasingly important environmental concern due to its visible negative impact on human health. However, air pollution also affects agricultural crops or food security directly or indirectly, which has not so far received sufficient attention. In this overview, we take ozone $\left(\mathrm{O}_{3}\right)$ as an example to analyze the principles and extent of the impact of air pollution on food security in China based on a review of the literature. Current $\mathrm{O}_{3}$ pollution shows a clear negative impact on food security, causing around a $10 \%$ yield decrease for major cereal crops according to a large number of field studies around the world. The mean yield decrease of winter wheat is predicted to be up to $20 \%$ in China, based on the projection of future ground-level $\mathrm{O}_{3}$ concentration in 2020, if no pollution control measures are implemented. Strict mitigation of $\mathrm{NO}_{x}$ and $\mathrm{VOC}_{\mathrm{s}}$ (two major precursors of $\mathrm{O}_{3}$ ) emissions is crucial for reducing the negative impacts of ground-level $\mathrm{O}_{3}$ on food security. Breeding new crop cultivars with tolerance to high ground-level $\mathrm{O}_{3}$ should receive serious consideration in future research programs. In addition, integrated soil-crop system management will be an important option to mitigate the negative effects of elevated ground-level $\mathrm{O}_{3}$ on cereal crop production and food quality.
\end{abstract}

Keywords air pollution, ozone damage, anthropogenic activity, crop production, mitigation of reactive $\mathrm{N}$ emission

\section{Introduction}

Air pollution has been a serious environmental concern in China since the $1980 \mathrm{~s}^{[1,2]}$. Among various atmospheric

Received July 9, 2015; accepted August 12, 2015

Correspondence: liu310@cau.edu.cn pollutants (e.g., fine particulate matter, $\mathrm{NO}_{x}, \mathrm{SO}_{2}$ and $\left.\mathrm{VOC}_{\mathrm{s}}\right)$, ground-level ozone $\left(\mathrm{O}_{3}\right)$ has been assumed to be the most phytotoxic air pollutant due to significant damage to plants and the rising trend in the concentration at a regional scale ${ }^{[3]}$. With the rapid industrialization and urbanization over the last two decades, $\mathrm{O}_{3}$ concentration has risen at a much higher rate in China than in other countries and the mean daily ( $24 \mathrm{~h}$ average) $\mathrm{O}_{3}$ concentration reaches more than $50 \mathrm{ppb}$ during the crop growing season in some regions of China ${ }^{[4,5]}$. Ground-level $\mathrm{O}_{3}$ concentration in China coincided with the emission of $\mathrm{NO}_{x}$ because the latter is one of the most important precursors of $\mathrm{O}_{3}{ }^{[6-8]}$. Published results show that ambient $\mathrm{O}_{3}$ concentrations with an average of $40 \mathrm{ppb}$ have significantly decreased the yield of major food crops (including potato, rice, soybean and wheat) by about $10 \%$ compared with $\mathrm{O}_{3}$ free air ${ }^{[9]}$. A field survey around Beijing found a total of 28 species or cultivars exhibiting typical symptoms of $\mathrm{O}_{3}$ damage $^{[10]}$. Therefore, it can be inferred that food security in China is being or has already been affected by current $\mathrm{O}_{3}$ concentrations and this damage will continue in the future. In this manuscript, we review the current and future $\mathrm{O}_{3}$ pollution, and its impacts on the production of food crop throughout China.

\section{Current situation of ground-level $\mathrm{O}_{3}$ pollution in China}

$\mathrm{O}_{3}$ exists in both stratosphere and troposphere. Stratospheric $\mathrm{O}_{3}$ is commonly known as good $\mathrm{O}_{3}$, because it absorbs ultraviolet light harmful to living things and prevents it from reaching ground. The loss of this $\mathrm{O}_{3}$, caused by chlorofluorocarbons and other substances, induces increasing UV-B radiation - a serious global environmental problem. 
In contrast, tropospheric $\mathrm{O}_{3}$ is known as bad $\mathrm{O}_{3}$ due to its greenhouse effect and toxicity. In the troposphere, $\mathrm{O}_{3}$ absorbs infrared rays emanating from the Earth and its radiative power ranks third in the atmosphere after carbon dioxide and methane ${ }^{[11]}$. The greenhouse effect of this $\mathrm{O}_{3}$ is more significant in the upper troposphere than in other layers. However, $\mathrm{O}_{3}$ at ground level mainly acts as a major air pollutant and is one of the main oxidants. It is also known to cause photochemical smog, which disturbs human respiratory functions and plant photosynthesis. Ground-level $\mathrm{O}_{3}$ is produced from the photochemical reaction of nitrogen oxides $\left(\mathrm{NO}_{x}\right)$ and volatile organic compounds $\left(\mathrm{VOC}_{\mathrm{s}}\right.$ ) under sunlight (Fig. 1). The amount of $\mathrm{O}_{3}$ generated by photochemical reaction of air pollutants is much larger than the inflow from the stratosphere. Therefore, $\mathrm{O}_{3}$ concentrations are strongly affected by human activities.

Tropospheric $\mathrm{O}_{3}$ has been a global air pollution problem. Currently, the $\mathrm{O}_{3}$ concentration on a global scale has reached about $40 \mathrm{ppb}$ due to a high use of fossil fuels and it has risen at a rate of $0.5 \%-2.0 \%$ per year since the preindustrial era ${ }^{[11]} \cdot \mathrm{O}_{3}$ pollution is highest in Central Europe, Eastern China, and the Eastern USA in the world. In Europe, the highest $\mathrm{O}_{3}$ levels occur in Central and Southern Europe ${ }^{[3]}$. Nearly one quarter of the earth's surface is currently at risk from elevated $\mathrm{O}_{3}$ concentrations in excess of $60 \mathrm{ppb}$ during midsummer, with even greater concentrations occurring locally ${ }^{[12]}$. Models have pre- dicted that tropospheric $\mathrm{O}_{3}$ concentration could rise by 20\%-25\% between 2015 and 2050, and further increase by $40 \%-60 \%$ by 2100 , if current emission trends continue ${ }^{[13]}$.

In most parts of China, ground-level $\mathrm{O}_{3}$ has been the main air pollutant in summer due to the high emission of $\mathrm{NO}_{x}$ from a rapid increase in the number and use of automobiles. The highest hourly $\mathrm{O}_{3}$ concentration was observed to be $316 \mathrm{ppb}$ in the North China Plain ${ }^{[14]}$. In recent years, the summertime $\mathrm{O}_{3}$ concentration frequently exceeded the second national standard level (i.e., hourly $\mathrm{O}_{3}$ concentration: $200 \mu \mathrm{g} \cdot \mathrm{m}^{-3}$ or approximately $100 \mathrm{ppb}$ ) for human health issued by the Chinese Environmental Protection Agency. Due to unbalanced development in the economy and in urbanization between regions, $\mathrm{O}_{3}$ concentrations differ among geographical locations. In the central and northern part of China, the $\mathrm{O}_{3}$ reaches a maximum in summer. However, in southern China, the $\mathrm{O}_{3}$ concentration is generally characterized by a peak in fall and a trough in summer ${ }^{[6,7]}$. On the monthly-mean basis, ground-level $\mathrm{O}_{3}$ peaks in May in the Yangtze River Delta, June in the North China Plain, and October in the Pearl River Delta ${ }^{[15]}$. The annual mean background $\mathrm{O}_{3}$ concentration over China shows a spatial gradient from $33.7 \mathrm{ppb}$ in the South China to $23.5 \mathrm{ppb}$ in the North and North-east China ${ }^{[6,7]}$.

Due to significant $\mathrm{NO}_{x}$ titration effect in cities, $\mathrm{O}_{3}$ concentration is lower in cities than rural regions. Fig. 2 shows the diurnal $\mathrm{O}_{3}$ concentration monitored in the city

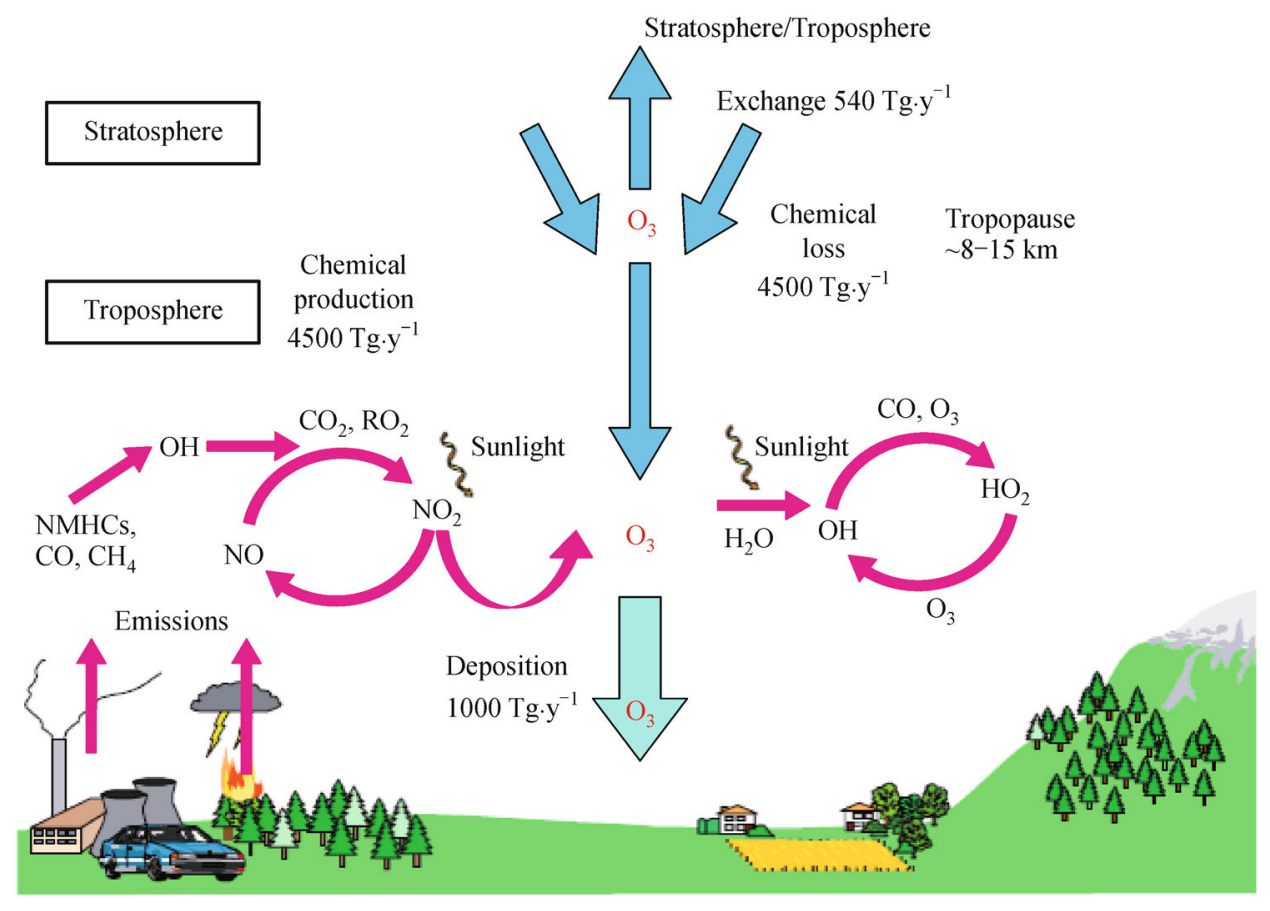

Fig. 1 A schematic view of the sources and sinks of ozone $\left(\mathrm{O}_{3}\right)$ in the troposphere ${ }^{[3]}$. Besides $\mathrm{O}_{3}$ deposition directly from stratosphere to troposphere, secondarily $\mathrm{O}_{3}$ in the troposphere formed from reactions of $\mathrm{NO}_{x}$ (sum of $\mathrm{NO}$ and $\mathrm{NO}_{2}$ ) and $\mathrm{VOC}_{\mathrm{s}}(\mathrm{e} . \mathrm{g}$., $\mathrm{NMHC}, \mathrm{CH}$, $\mathrm{CO}$ ) under sunlight is the major contributor to surface $\mathrm{O}_{3}$ on earth. 
and cropland in rural regions. The peak of $\mathrm{O}_{3}$ concentration in rural regions appears earlier and it lasts longer from 3 to 4 p.m. to 8 p.m. in urban regions compared with rural regions. This $\mathrm{O}_{3}$ concentration difference is quite common. Furthermore, the emission of $\mathrm{NO}_{x}$ in China will continue increasing for some decades due to the rapid rise in the use of automobiles and industrial activity ${ }^{[6,7]}$, so the concentrations of ground-level $\mathrm{O}_{3}$ are predicted to increase in the future. Therefore, it can be inferred that the high groundlevel $\mathrm{O}_{3}$ concentration in China, particularly in rural regions, negatively affect food security given that the measured concentrations exceed the critical level of $\mathrm{O}_{3}$ for crop production ${ }^{[16]}$.

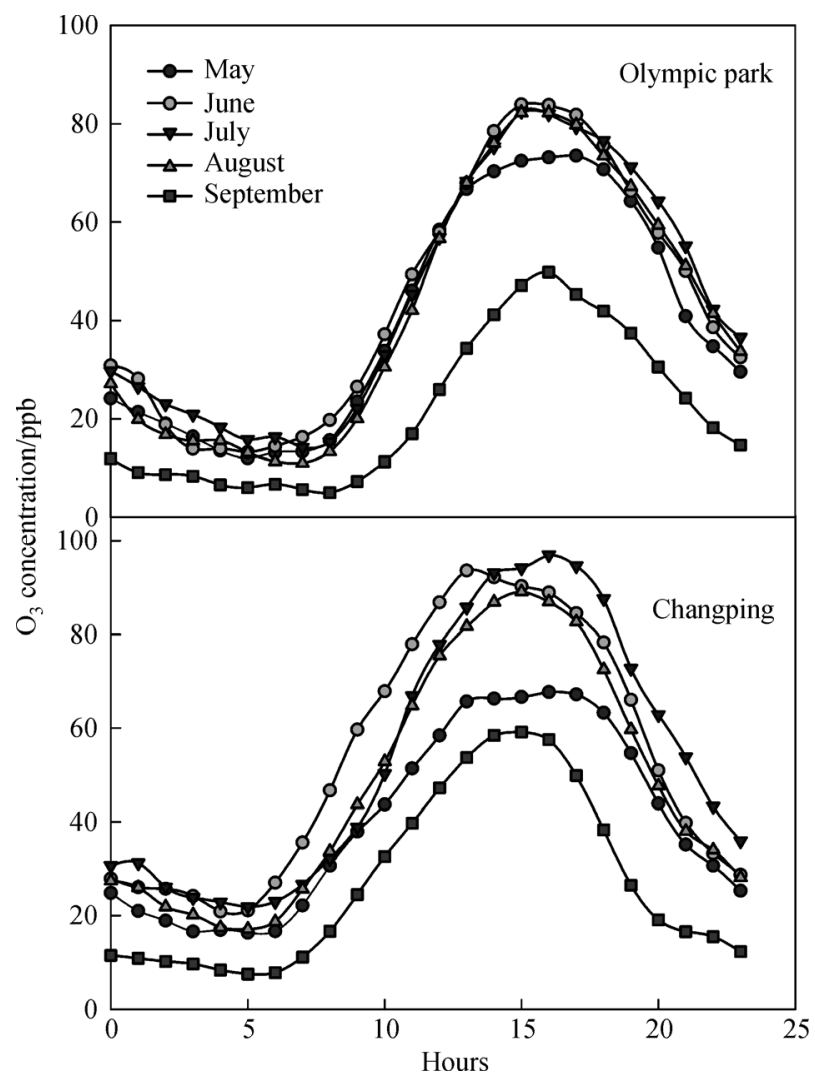

Fig. 2 The diurnal change of ground-level $\mathrm{O}_{3}$ concentration in the ambient air monitored in the city (Olympic park, city center of Beijing) and over cropland (Changping, rural region of Beijing). Highest $\mathrm{O}_{3}$ concentration was recorded from 1 to 5 p.m., while lowest $\mathrm{O}_{3}$ concentration occurred in the early morning (5 to 6 a.m.) at both locations.

\section{Effect of air pollution by $\mathrm{O}_{3}$ on food security in China}

3.1 Mechanisms of ground-level $\mathrm{O}_{3}$ pollution affecting crop production and food security

The phytotoxicity of $\mathrm{O}_{3}$ to plants derives primarily from its oxidative damage to the plasma membranes ${ }^{[17]}$. Heath et al. ${ }^{[18]}$ reviewed the interaction of $\mathrm{O}_{3}$ and plant tissues, and proposed three distinct processes: external $\mathrm{O}_{3}$ concentration, uptake, and detoxification. It is well known that $\mathrm{O}_{3}$ penetrates plant leaves through open stomata and dissolves into the apoplastic fluid, suggesting that plants with large stomatal conductance would allow a higher $\mathrm{O}_{3}$ uptake, and thus experience more damage ${ }^{[19-21]}$. Following its entry into leaves through open stomata, $\mathrm{O}_{3}$ is dissolved in the liquid phase of the apoplastic space surrounding the substomatal cavity ${ }^{[22,23]}$, and produces a series of reactive oxygen species including hydroxyl radical, singlet oxygen and hydrogen peroxide, which could cause severe damage to cellular components such as membranes and chloroplasts ${ }^{[24-26]}$. High $\mathrm{O}_{3}$ concentration also reduces the central biochemical processes controlling photosynthesis, such as the maximum carboxylation efficiency, and the maximum rate of ribulose bisphosphate regeneration $^{[27,28]}$, thus decreasing the light and dark reactions of photosynthesis, causing a range of adverse effects on plants including reduced photosynthetic activity, altered carbon allocation, diminished biomass accumulation, reduced yield and accelerated senescence, with or without visible injury ${ }^{[28-30]}$. Ground-level $\mathrm{O}_{3}$ pollution negatively affects grain yield and quality of food crops mainly due to its oxidative damage during the growth period in particular the grain filling stage.

\subsection{Effect of $\mathrm{O}_{3}$ pollution on cereal crop production and food quality}

Experiments in Europe, Japan and the United States indicate that yield losses of agricultural crops may occur even under current $\mathrm{O}_{3}$ concentrations. Surrounding Beijing, 28 plant species/cultivars including amenity trees, natural forest species and crops (e.g., peanut and snap bean) were found with typical $\mathrm{O}_{3}$ symptoms during a recent $\mathrm{O}_{3}$ injury survey ${ }^{[10]}$. On the basis of open-top chamber results, a meta-analysis showed that the yield of cereal crops including rice, soybean and wheat was reduced by about $8 \%$ when ambient $\mathrm{O}_{3}$ concentration reach $40 \mathrm{ppb}^{[9]}$. This suggests that food production in China will be partly reduced by the current $\mathrm{O}_{3}$ concentrations. There have been some field studies to investigate the impact of elevated $\mathrm{O}_{3}$ on the food crops (winter wheat, rice and oilseed rape) and details can be found in a review by Feng et al. ${ }^{[6]}$.

In an open top chamber experiment lasting 5 years, wheat yields decreased by $8.5 \%-58.0 \%$ and $40 \%-73 \%$ and rice yields by $10 \%-34 \%$ and $16 \%-43 \%$ as compared with charcoal filtered air for $\mathrm{O}_{3}-1$ ( 75 or $100 \mathrm{ppb}$ ) and $\mathrm{O}_{3}-2$ $(150$ or $200 \mathrm{ppb})$ treatments ${ }^{[31]}$, respectively. While at the Jiangdu site, a mean of $25 \%$ enhancement above the ambient $\mathrm{O}_{3}$ concentration $\left(\mathrm{A}-\mathrm{O}_{3}, 45.7 \mathrm{ppb}\right)$ reduced grain yield in winter wheat by $20 \%$ with significant variation in the range from $10 \%$ to $35 \%$ among the various combinations of cultivar and season ${ }^{[30]}$. In rice, elevated $\mathrm{O}_{3}$ also 
reduced the grain yield by $12 \%$ on average across four cultivars. However, there were large differences in the extent of these yield losses ${ }^{[32]}$. These reduced yields caused by $\mathrm{O}_{3}$ pollution were similar to a recent report by Rai and Agrawal ${ }^{[33]}$, who summarized the impact of tropospheric $\mathrm{O}_{3}$ on crop plants worldwide. However, the quantitative assessment of ambient $\mathrm{O}_{3}$ effects on food crop yield is rare in China. It is necessary to launch large joint programs to assess the current $\mathrm{O}_{3}$ effects on food crop production and develop a critical $\mathrm{O}_{3}$ standard to protect crops against $\mathrm{O}_{3}$.

Due to the limited number of $\mathrm{O}_{3}$ impact studies in China and large regional differences in climate, cultivars and management, there are many uncertainties to assess when studying the $\mathrm{O}_{3}$ effects on food crops in China. So far, there have been only three studies estimating the yield loss of food crops at current and projected $\mathrm{O}_{3}$ concentrations on a national scale, and there were large differences in $\mathrm{O}_{3}$ dose responses, even within each study ${ }^{[6,7]}$. Of these, only the study by Tang et al. ${ }^{[4]}$ is based on the one dose-response relationship from the field experiment of four local cultivars in subtropical regions of China. Their results indicated that the ground-level $\mathrm{O}_{3}$ concentration in 2000 caused an estimated yield loss in wheat of $6.4 \%-15.0 \%$ throughout China. Projected to 2020 , the $\mathrm{O}_{3}$ is estimated to induce yield loss of winter wheat in China of $15 \%-23 \%{ }^{[4]}$, which is much higher than the results from Aunan et al. ${ }^{[34]}$ and Wang and Mauzerall ${ }^{[35]}$.

On the basis of research conducted in open-top chambers and $\mathrm{O}_{3}$-free air concentration enrichment, a recent meta-analysis on grain quality of wheat in response to $\mathrm{O}_{3}$ showed that $\mathrm{O}_{3}$ significantly decreased starch concentration. $\mathrm{O}_{3}$ increased grain protein content and the concentration of several nutritionally important minerals $(\mathrm{P}, \mathrm{K}, \mathrm{Ca}, \mathrm{Mg}, \mathrm{Cu}, \mathrm{Zn}$, and $\mathrm{Mn})$, but reduced yield ${ }^{[29,36]}$. Some baking properties (Zeleny value and Hagberg falling number) were positively influenced by ground-level $\mathrm{O}_{3}{ }^{[36]}$.

It is projected that $\mathrm{NO}_{x}, \mathrm{VOC}_{\mathrm{s}}$ and $\mathrm{O}_{3}$ concentrations will continue to rise in China in the future. It can be inferred that crops will be exposed to higher levels of $\mathrm{O}_{3}$ stress, and economic losses will affect not only China but also the neighboring countries (e.g., Japan, Korea, Europe, USA) through long-range transport of both $\mathrm{NO}_{x}$ and $\mathrm{O}_{3}$.

\section{Policy recommendations to tackle negative effects of ground-level $\mathrm{O}_{3}$ pollution on food security}

4.1 Reducing ground-level $\mathrm{O}_{3}$ concentration by mitigating anthropogenic $\mathrm{NO}_{x}$ and $\mathrm{VOC}_{\mathrm{s}}$ emissions

In Europe and North America, air quality and ground-level $\mathrm{O}_{3}$ concentration has decreased substantially with strict air pollution control measures implemented since the $1990 \mathrm{~s}^{[37]}$. Most of the ground-level $\mathrm{O}_{3}$ was produced from the photochemical reaction of $\mathrm{NO}_{x}$ and $\mathrm{VOC}_{\mathrm{s}}$ under sunlight. Therefore, the most effective measure to reduce $\mathrm{O}_{3}$ concentration is to mitigate the emissions of $\mathrm{O}_{3}$ precursors such as $\mathrm{NO}_{x}$ and $\mathrm{VOC}_{\mathrm{s}}$, which are mainly from automotive exhaust. Three national actions by policy makers will be implemented in order to achieve the goal of lower ground-level $\mathrm{O}_{3}$ pollution. The first action is to use the Euro standard V for automotive exhaust, which will be enforced throughout China by 2020. The second is to use electric vehicles widely, which has been encouraged by the central and local governments through different preferential policies, such as refunds and tax exemptions. The third is to reduce the total number of automobiles (especially private cars) on road by further developing public transportation in major and populous cities, increasing parking charges and taxation of cars entering city centers.

\subsection{Breeding crop cultivars tolerant to ground-level $\mathrm{O}_{3}$ pollution}

Due to the fact that plant species and cultivars vary greatly in tolerance ${ }^{[20,27,38,39]}$, breeding $\mathrm{O}_{3}$-tolerant genotypes is a further good method to reduce yield loss. Some genes conferring $\mathrm{O}_{3}$ tolerance have been found in rice and soybean $^{[40-42]}$ and $\mathrm{O}_{3}$ tolerance genes could be added to other crops using modern molecular biology techniques. There is a strong need for new crop breeding programs to include breeding crop cultivars tolerant to air pollution. This is especially urgent for $\mathrm{O}_{3}$ tolerant breeding as ground-level $\mathrm{O}_{3}$ concentrations are rapidly increasing in developing nations like China and India.

\subsection{Integrated soil-crop system management for reducing ground-level $\mathrm{O}_{3}$ pollution impacts}

Besides air pollution control measures and adoption of $\mathrm{O}_{3}$ tolerant crop cultivars, integrated soil-crop system management ${ }^{[43,44]}$ is another important option to improve food security and nutrient resource use efficiency even with air pollution such as elevated $\mathrm{O}_{3}$. The integrated soil-crop system management will promote a healthy crop canopy formation and match crop nutrient requirement by supplying nutrients in both space and time (Fig.3). Therefore the soil-crop system management measures (including optimized plant density, crop residue retention, and real-time $\mathrm{N}$ management) will help to build a good buffering system for crops even under $\mathrm{O}_{3}$ pollution. Although no field studies have systematically evaluated the impact of integrated soil-crop system management on crop yield, we believe at least half of the yield loss can be avoided by such integrated measures. For example, Hewitta et al. ${ }^{[45]}$ observed that $\mathrm{N}$ management, as part of soil-crop system management, is essential to prevent tropical oil palm plantations from ground-level $\mathrm{O}_{3}$ pollution. Future studies of the effects of ground-level $\mathrm{O}_{3}$ 


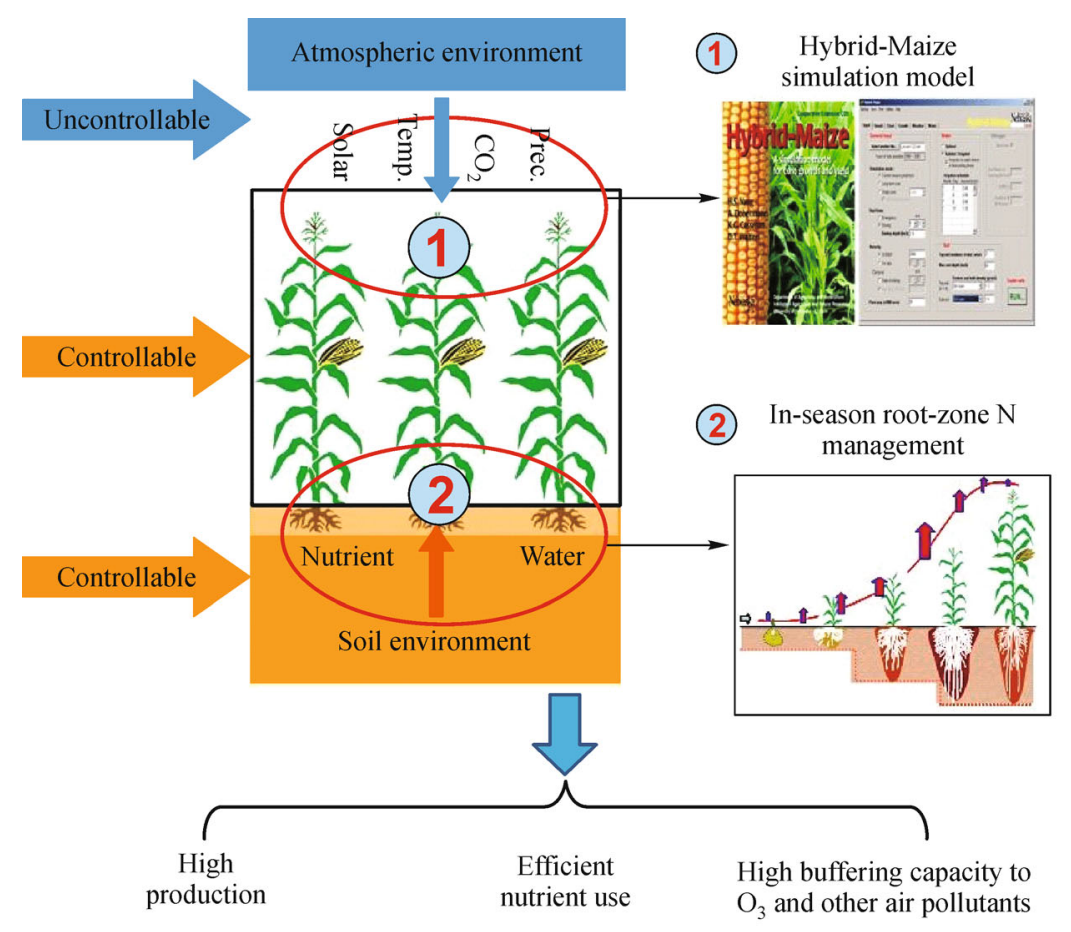

Fig. 3 Diagram of integrated soil-crop system management for high yield, high efficiency and high buffering capacity to air pollution by $\mathrm{O}_{3}$ (taking maize as an example, modified from Chen et al. ${ }^{[43]}$ ). Part 1 refers to optimized crop canopy and part 2 refers to soil nutrient (e.g., N) management in time and space.

pollution should evaluate the effectiveness of integrated soil-crop system management on the production and grain quality of food crops.

\section{Conclusions}

With continuing increases in emissions of $\mathrm{O}_{3}$ precursors such as $\mathrm{NO}_{x}$ and VOCs in China with its rapid economic growth, air pollution, especially ground-level $\mathrm{O}_{3}$ will increase drastically over the coming decades. There is a lack of systematic studies on air pollution effects on crop production and food security in China. Based on a limited literature search, we have selected $\mathrm{O}_{3}$ pollution as an example to demonstrate the principles and extents of air pollution impact on food security in China. Current $\mathrm{O}_{3}$ pollution can cause $6.4 \%-15.0 \%$ yield loss for major cereal crops according to a number of $\mathrm{O}_{3}$-free air concentration enrichment studies. The mean yield loss of cereal crops could reach more than $20 \%$ according to the ground-level $\mathrm{O}_{3}$ concentrations projected for 2020. To avoid yield damage by $\mathrm{O}_{3}$ pollution, three strategies need to be seriously considered for the future. The first strategy is strict mitigation of $\mathrm{NO}_{x}$ and $\mathrm{VOC}_{\mathrm{s}}$ emissions to reduce the ground-level $\mathrm{O}_{3}$ concentration and its negative impact on food security. The second strategy is to breed and adopt new crop cultivars tolerant to high ground-level $\mathrm{O}_{3}$ concentrations. The third strategy is to adopt integrated soil-crop system management, which will improve food security via increasing the buffering capacity of the soilcrop ecosystems to various air pollutants including $\mathrm{O}_{3}$.

Acknowledgements This work was financially supported by the China National Funds for Distinguished Young Scientists (40425007), the Hundred Talents Program of Chinese Academy of Sciences (CAS), and State Key Laboratory of Urban and Regional Ecology, Research Center for EcoEnvironmental Sciences, CAS.

Compliance with ethics guidelines Zhaozhong Feng, Xuejun Liu, and Fusuo Zhang declare that they have no conflict of interest or financial conflicts to disclose.

This article does not contain any studies with human or animal subjects performed by any of the authors.

\section{References}

1. Chan $\mathrm{C} \mathrm{K}$, Yao X H. Air pollution in mega cities in China. Atmospheric Environment, 2008, 42(1): 1-42

2. Zhao D W, Sun B Z. Air pollution and acid rain in China. Ambio, 1986, 15: 2-5

3. The Royal Society. Ground-level ozone in the 21 st century: future trends, impacts and policy implications. The Royal Society, 2008, Science Policy Report 15/08: 1-132

4. Tang H, Takigawa M, Liu G, Zhu J, Kobayashi K. A projection of ozone-induced wheat production loss in China and India for the years 2000 and 2020 with exposure-based and flux-based 
approaches. Global Change Biology, 2013, 19(9): 2739-2752

5. Zhao C, Wang Y, Zeng T. East China plains: a "basin" of ozone pollution. Environmental Science \& Technology, 2009, 43(6): 19111915

6. Feng Z, Hu E, Wang X, Jiang L, Liu X. Ground-level $\mathrm{O}_{3}$ pollution and its impacts on food crops in China: a review. Environmental Pollution, 2015, 199: 42-48

7. Feng Z, Paoletti E, Bytnerowicz A, Harmons H. Ozone and Plants. Environmental Pollution, 2015, 202: 215-216

8. Liu X, Duan L, Mo J, Du E, Shen J, Lu X, Zhang Y, Zhou X, He C, Zhang F. Nitrogen deposition and its ecological impact in China: an overview. Environmental Pollution, 2011, 159(10): 2251-2264

9. Feng Z, Kobayashi K. Assessing the impacts of current and future concentrations of surface ozone on crop yield with meta-analysis. Atmospheric Environment, 2009, 43(8): 1510-1519

10. Feng Z, Sun J, Wan W, Hu E, Calatayud V. Evidence of widespread ozone-induced visible injury on plants in Beijing, China. China Environmental Pollution., 2014, 193: 296-301

11. Intergovernmental Panel on Climate Change. Summary for Policymakers. In: Stocker T F, Qin D, Plattner G K, Tignor M, Allen S K, Boschung J, Nauels A, Xia Y, Bex V Midgley P M, eds. Climate change 2013: the physical science basis. Cambridge: Cambridge University Press, 2013

12. Fowler D, Cape J N, Coyle M, Smith R I, Hjellbrekke A G, Simpson D, Derwent R G, Johnson C E. Modelling photochemical oxidant formation, transport, deposition and exposure of terrestrial ecosystems. Environmental Pollution, 1999, 100(1-3): 43-55

13. Meehl G A, Stocker T F, Collins W D, Friedlingstein P, Gaye A T, Gregory J M, Kitoh A, Knutti R, Murphy J M, Noda A, Raper S C B, Watterson I G, Weaver A J, Zhao Z C. Global climate projections, In: Solomon S, Qin D, Manning M, Chen Z, Marquis M, Averyt K B, Tignor M, Miller H L, eds. Climate change 2007: the physical science basis. Cambridge: Cambridge University Press, 2007

14. Yin Y Q, Li C M, Ma G X, Cui Z J. Ozone concentration distribution of urban. Environmental Sciences, 2004, 25(6): 16-20

15. Wang Y, Zhang Y, Hao J, Luo M. Seasonal and spatial variability of surface ozone over China: contributions from background and domestic pollution. Atmospheric Chemistry and Physics, 2011, 11 (7): 3511-3525

16. Convention L R T A P. Mapping critical levels for vegetation, manual on methodologies and criteria for modeling and mapping critical loads \& levels and air pollution effects, risk and trends. Available at ICP Vegetation Website on September 28, 2014

17. Schraudner M, Langebartels C, Sandermann H. Changes in the biochemical status of plant cells induced by the environmental pollutant ozone. Physiologia Plantarum, 1997, 100(2): 274-280

18. Heath R L, Lefohn A S, Musselman R C. Temporal processes that contribute to nonlinearity in vegetation responses to ozone exposure and dose. Atmospheric Environment, 2009, 43(18): 2919-2928

19. Pleijel H, Eriksen A B, Danielsson H, Bondesson N, Sellden G. Differential ozone sensitivity in an old and a modern Swedish wheat cultivar - grain yield and quality, leaf chlorophyll and stomatal conductance. Environmental and Experimental Botany, 2006, 56(1): 63-71

20. Biswas D K, Xu H, Li Y G, Sun J Z, Wang X Z, Han X G, Jiang G
M. Genotypic differences in leaf biochemical, physiological and growth responses to ozone in 20 winter wheat cultivars released over the past 60 years. Global Change Biology, 2008, 14: 46-59

21. Feng Z, Tang H, Uddling J, Pleijel H, Kobayashi K, Zhu J, Oue H, Guo W. A stomatal ozone flux-response relationship to assess ozone-induced yield loss of winter wheat in subtropical China. Environmental Pollution, 2012, 164: 16-23

22. Fiscus E L, Booker F L, Burkey K O. Crop responses to ozone: uptake, modes of action, carbon assimilation and partitioning. Plant, Cell \& Environment, 2005, 28(8): 997-1011

23. Laisk A, Kull O, Moldau H. Ozone concentration in leaf intercellular air spaces is close to zero. Plant Physiology, 1989, 90(3): 1163-1167

24. Langebartels C, Wohlgemuth H, Kschieschan S, Grun S, Sandermann H. Oxidative burst and cell death in ozone-exposed plants. Plant Physiology and Biochemistry, 2002, 40(6-8): 567-575

25. Turcsányi E, Lyons T, Plöchl M, Barnes J. Does ascorbate in the mesophyll cell walls form the first line of defence against ozone? Testing the concept using broad bean (Vicia faba L.). Journal of Experimental Botany, 2000, 51(346): 901-910

26. Wang J, Zeng Q, Zhu J, Chen C, Liu G, Tang H. Apoplastic antioxidant enzyme responses to chronic free-air ozone exposure in two different ozone-sensitive wheat cultivars. Plant Physiology and Biochemistry, 2014, 82: 183-193

27. Feng Z, Pang J, Kobayashi K, Zhu J, Ort D R. Differential responses in two varieties of winter wheat to elevated ozone concentration under fully open-air field conditions. Global Change Biology, 2011, 17(1): 580-591

28. Zhang W, Wang G, Liu X, Feng Z. Effects of elevated $\mathrm{O}_{3}$ exposure on seed yield, $\mathrm{N}$ concentration and photosynthesis of nine soybean cultivars (Glycine $\max$ (L.) Merr.) in Northeast China. Plant Science, 2014, 226: 172-181

29. Feng Z, Kobayashi K, Ainsworth E A. Impact of elevated ozone concentration on growth, physiology and yield of wheat (Triticum aestivum L.): a meta-analysis. Global Change Biology, 2008, 14: 2696-2708

30. Zhu X, Feng Z, Sun T, Liu X, Tang H, Zhu J, Guo W, Kobayashi K. Effects of elevated ozone concentration on yield of four Chinese cultivars of winter wheat under fully open-air field conditions. Global Change Biology, 2011, 17(8): 2697-2706

31. Wang X, Zhang Q, Zheng F, Zheng Q, Yao F, Chen Z, Zhang W, Hou P, Feng Z, Song W, Feng Z, Lu F. Effects of elevated $\mathrm{O}_{3}$ concentration on winter wheat and rice yields in the Yangtze River Delta, China. Environmental Pollution, 2012, 171: 118-125

32. Shi G, Yang L, Wang Y, Kobayashi K, Zhu J, Tang H, Pan S, Chen $\mathrm{T}$, Liu G, Wang Y. Impact of elevated ozone concentration on yield of four Chinese rice cultivars under fully open-air field conditions. Agriculture, Ecosystems \& Environment, 2009, 131(3-4): 178-184

33. Rai R, Agrawal M. Impact of tropospheric ozone on crop plants. Proceedings of the National Academy of Sciences of the United States of America, 2012, 82: 241-257

34. Aunan K, Berntsen T K, Seip H M. Surface ozone in China and its possible impact on agricultural crop yields. Ambio, 2000, 29(6): 294-301

35. Wang X, Mauzerall D L. Characterizing distributions of surface 
ozone and its impact on grain production in China, Japan and South Korea: 1990 and 2020. Atmospheric Environment, 2004, 38(26): 4383-4402

36. Broberg M C, Feng Z, Xin Y, Pleijel H. Ozone effects on wheat grain quality - a summary. Environmental Pollution, 2015, 197: 203-213

37. Sutton M A, Bleeker A., Howard C M, Bekunda M, Grizzetti B, de Vries W, van Grinsven H J M, Abrol Y P, Adhya T K, Billen G, Davidson E A, Datta A, Diaz R, Erisman J W, Liu X J, Oenema O, Palm C, Raghuram N, Reis S, Scholz R W, Sims T, Westhoek H, Zhang F S. Our nutrient world: the challenge to produce more food and energy with less pollution. Edinburgh: NERC/Centre for Ecology \& Hydrology, 2013

38. Flowers M D, Fiscus E L, Burkey K O, Booker F L, Dubois J J B. Photosynthesis, chlorophyll fluorescence, and yield of snap bean (Phaseolus vulgaris L.) genotypes differing in sensitivity to ozone. Environmental and Experimental Botany, 2007, 61(2): 190-198

39. Zhang W, Feng Z, Wang X, Niu J. Responses of native broadleaved woody species to elevated ozone in subtropical China. Environmental Pollution, 2012, 163: 149-157

40. Frei M, Tanaka J P, Chen C P, Wissuwa M. Mechanisms of ozone tolerance in rice: characterization of two QTLs affecting leaf bronzing by gene expression profiling and biochemical analyses. Journal of Experimental Botany, 2010, 61(5): 1405-1417

41. Frei M. Breeding of ozone resistant rice: relevance, approaches and challenges. Environmental Pollution, 2015, 197: 144-155

42. Gillespie K M, Rogers A, Ainsworth E A. Growth at elevated ozone or elevated carbon dioxide concentration alters antioxidant capacity and response to acute oxidative stress in soybean (Glycine max). Journal of Experimental Botany, 2011, 62(8): 2667-2678

43. Chen X P, Cui Z L, Vitousek P M, Cassman K G, Matson P A, Bai J S, Meng Q F, Hou P, Yue S C, Römheld V, Zhang F S. Integrated soil-crop system management for food security. Proceedings of the National Academy of Sciences of the United States of America, 2011, 108(16): 6399-6404

44. Chen X, Cui Z, Fan M, Vitousek P, Zhao M, Ma W, Wang Z, Zhang W, Yan X, Yang J, Deng X, Gao Q, Zhang Q, Guo S, Ren J, Li S, Ye Y, Wang Z, Huang J, Tang Q, Sun Y, Peng X, Zhang J, He M, Zhu Y, Xue J, Wang G, Wu L, An N, Wu L, Ma L, Zhang W, Zhang F. Producing more grain with lower environmental costs. Nature, 2014, 514(7523): 486-489

45. Hewitt C N, MacKenzie A R, Di Carlo P, Di Marco C F, Dorsey J R, Evans M, Fowler D, Gallagher M W, Hopkins J R, Jones C E, Langford B, Lee J D, Lewis A C, Lim S F, McQuaid J, Misztal P, Moller S J, Monks P S, Nemitz E, Oram D E, Owen S M, Phillips G J, Pugh T A M, Pyle J A, Reeves C E, Ryder J, Siong J, Skiba U, Stewart D J. Nitrogen management is essential to prevent tropical oil palm plantations from causing ground-level ozone pollution. Proceedings of the National Academy of Sciences of the United States of America, 2009, 106(44): 18447-18451 